\section{ル・コルビュジエ設計『巡礼者 の家』実測調査報告}

\section{REPORT OF MEASUREMENT SURVEY OF MAISON DES PĖLERINS DESIGNED BY LE CORBUSIER}

\author{
白石哲雄 — * 1 山田浩史 — $* 2$ \\ 藤井由理 — $* 3$ 古谷誠章 $-* 4$ \\ キーワード : \\ ル・コルビュジエ, ロンシャンの礼拝堂, 巡礼者の家, ミュロンダン, \\ トレンカディス
}

Keywords:

Le Corbusier, Chapelle Notre Dame du Haut, Maison des Pèlerins, Murondin, Trencadis

\section{1.はじめに}

\section{1 研究目的}

本稿ではル・コルビュジェ Le Corbusier (1987-1965) によってフ ランス・ロンシャンに設計された巡礼者の家 Maison des Pèlerins （1952-1955）の実測調査の結果について取り上げる。筆者は管理団 体（慈善事業協会）である l'Association Euvre Notre Dame du Haut(以下、l'A.O.N.D.H と略記)より実測調查許可を取得し、同敷地 のノートル・ダム・デュ・オー礼择堂 Chapelle Notre Dame du Haut （1950-1955）（以下、礼拝堂と略記）及び司祭者の家 Maison du Gardian を含む実測調查を 2013 年より 4 年間に渡って実施してき た注1)。巡礼者の家の状況把握を通し、ロンシャンにおけるル・コル ビュジエの設計思想の一端を明らかにするとともに、竣工時から時 間が経過し老朽化が進む近代建築を調查・保存するための基礎調査 資料とすることを目的としている。

\section{2 研究対象 巡礼者の家について}

巡礼者の家は、礼拝堂を訪れる信者の宿泊施設として礼拝堂・司祭 者の家と同時期に設計された。丘の入口から礼拝堂へ向けて登る坂 道の途中に東側から直行するように配置されており、巡礼者のみが 宿泊を許可されていた（写真 1 )。書籍では全作品集において二枚の 外観写真と配置図、建物名注 2)が、Modulor II において内観写真 1 枚 注3)が確認できるのみで図面や文章などは掲載されていない。他の作 品集でも同様である。パリのル・コルビュジエ財団 FONDATION LE CORBUSIER 所蔵の全図版を収めた Plans 注4)では全 36 点が確認で きるが、世界文化遺産登録後の 2017 年まで一般公開されておらずこ れまで広く論考の対象となってこなかった。

\section{3 研究方法}

全体の実測調査を経て図面を作成し、設計図との比較検証、部分の 詳細把握を経て考察へと至る（表 1 )。施主の一人フランソワ・マテ 氏 Francois Mathey のご子息であり l'A.O.N.D.H 元副プレジデント

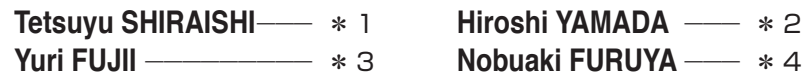

Authors carried out measurement investigation of Chapelle Notre Dame du Haut (1950-1955) designed by Le Corbusier in Ronchamp, France and Maison des Pèlerins. In this investigation, the present construction situation of Maison des Pèlerins was clarified. Morphological, positional, and color analyses revealed that the Chapelle Notre Dame du Haut was related to other elements in the whole hill of Ronchamp in terms of gaze and positional relationship, and it was concluded that the Maison des Pèlerins was a part of the "Integration and harmonization of the entire site" that Le Corbusier aimed at.
のジャン・フランソワ・マテ氏 Jean Francois Mathey（以下、マテ 氏と略記）の言説調查を行う。（2 章）次に実測調査を基に作成した 図面と原図の比較分析を行う。( 3 章) 続いて、実測結果を踏まえ、 形態・寸法・配置・色彩の各項目において検証を行う。( 4 章) 最後 にまとめを記述し終わりとする。礼拝堂やロンシャンの丘に関する 既往論文は多く存在するが、巡礼者の家に着目した研究は見られな い。本研究は礼扯堂、ロンシャンの丘の一連の研究、ル・コルビュジ エ研究に新たな視座を与えるものになることを期待している。

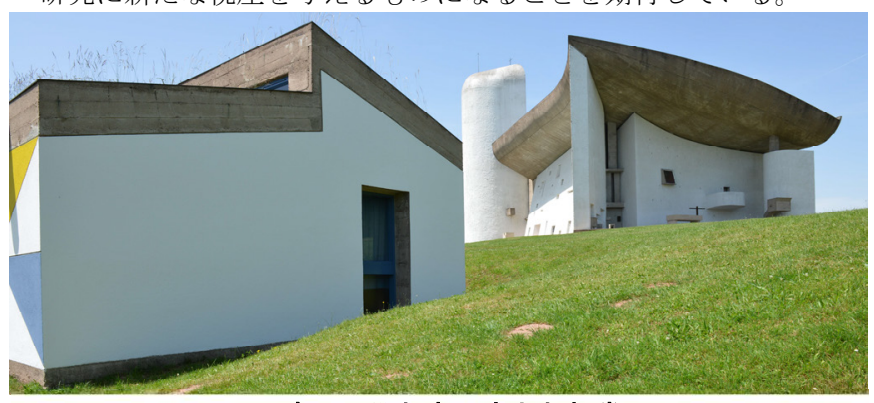

写真 1 巡礼者の家と礼拝堂

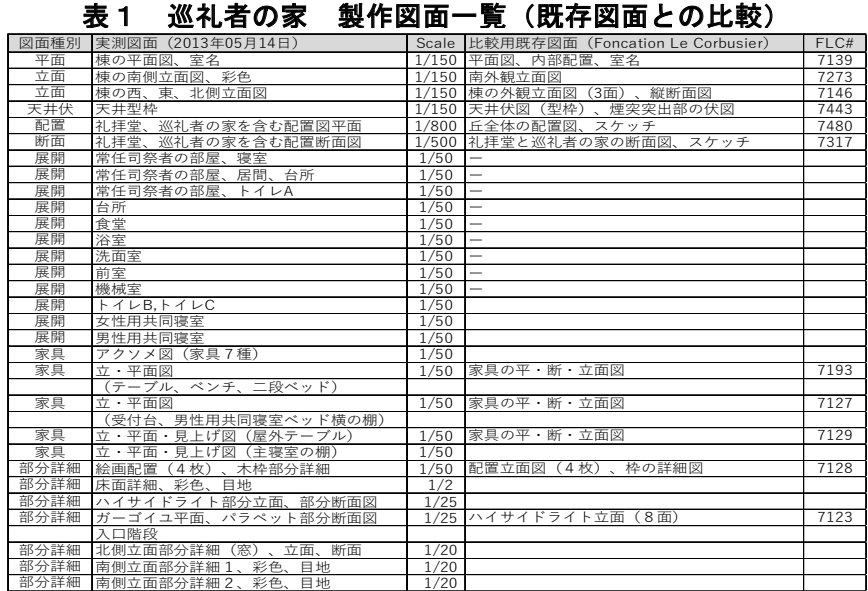

\footnotetext{
1 早稲田大学理工学術院 招聘研究員・工修

（₹ 169-8555 東京都新宿区大久保 3-4-1)

早稲田大学創造理工学部建築学科 助手・工修

早稲田大学創造理工学部建築学科 准教授・工修

早稲田大学創造理工学部建築学科 教授・工修
} 
2. ロンシャンの丘を巡るオーラルヒストリー

\section{1 ロンシャンの丘に関する時系列}

2014 年 06 月に行ったマテ氏へのインタビュー、そして 2016 年 8 月に日本で行われたマテ氏の講演内容の記録注 5)を基に、ロンシャン の丘におけるル・コルビュジエの一連の動きを辿った（表 2 ）。礼拝 堂に関する事項が書籍等で示されているものと同等であることを確 認した上で、巡礼者の家、司祭者の家の情報を付加していった。

\section{2 礼拝堂との一体化}

年表中部 1953 年時より、巡礼者の家は礼拝堂より先に建設を完了 し、本礼拝堂が完了寸るまでの間、仮として使用することが想定され ていた（赤枠上）。巡礼者の建設に関して、ル・コルビュジエは他の 思想を持ち込まず自分で設計することを主張し、ロンシャンの丘全 体を一体とした理念の実現を目指した。この巡礼者の家においても 礼拝堂と同じ設計思想が反映されていると捉えられ、両者の間に共 通項があることを強く導く事ができる。

\section{3 施設の公開状況}

1955 年の礼扯堂完成後は巡礼者の宿泊にのみ使用されてきたが、 2006 年に始まるレンゾ・ピアノ氏 Renzo Piano（1937-）によるゲー トハウスの計画時において現場管理のために事務所機能が 3 年間一 時的に移設されていた (赤枠中)。竣工後から世界文化遺産に登録さ れる間の期間に実測調查を行った。年表下部 2017 年時より、巡礼者 の家は入り口から食堂・トイレまでの範囲を限定的に一般開放され 始めた（赤枠下）。これは 2016 年に世界文化遺産に登録された後に 急増した観光客のトイレ利用のためである注 6)。

\section{3. 実測調查 実測図面の作成}

\section{1 実測図の作成}

本稿では巡礼者の家に限定して 2012-2013 年の成果をまとめてい る注7)。測量では Leica 製レーザー距離計 Disto D5 (測量誤差 $\pm 1.0 \mathrm{~mm}$ )、 Leica 製アダプターFTA360、Slik 製三脚、コンベックス、巻き尺、 色見本帳を用いている。躯体と距離計の位置関係を基準点として躯 体への墨出し器による水辺線投射後、互いの距離を定めた異なる 2 台 から同一点へ照射し、 $x, y, z$ 座標 3 点を取得。CAD ソフトにて点群 情報を打ち込んだのち各図面を作成した（図 1 ）。図面化の際には、 財団所蔵の既存図面から読み取ることのできた寸法である南側立面 横幅長さの $30250 \mathrm{~mm}$ を基準としている。3 回の実測によって取得し た平均值 302496.6mm とほぼ同一である。平面図の記述においては 本調查時に水平距離測定の始点とした南西部角を基準点として、各 辺を直角に重ねる形で作成を進めている注 8)。

\section{2 間仕切り壁の増築・減築}

実測図による検証の結果、竣工後に増築・減築された壁があること が確認された。食堂北側の壁（図 1 内赤線 : 増築）と、機械室の壁（図 1 内青線 : 減築のため現在なし) の 2 箇所である。マテ氏によれば手 が加えられた時期は不明だが、利便性を考慮して実施されたもので、 増設された壁は撤去可能な仕様であるという。食堂では礼拝堂側を 臨む北側の空（4.3 参照）を境界として収蔵室の前室を作るように間 仕切りが付加され、機械室では部屋の入口から奥へ出入りする通路 幅を確保するように床面から間仕切りが撤去されていた。既存図面 （FLC 7139）との照合により、設計時には食堂の壁が存在していな かったこと、機械室の壁が存在していたことを確認した（図 2 ）。
表 2 ロンシャンの丘 関連年表
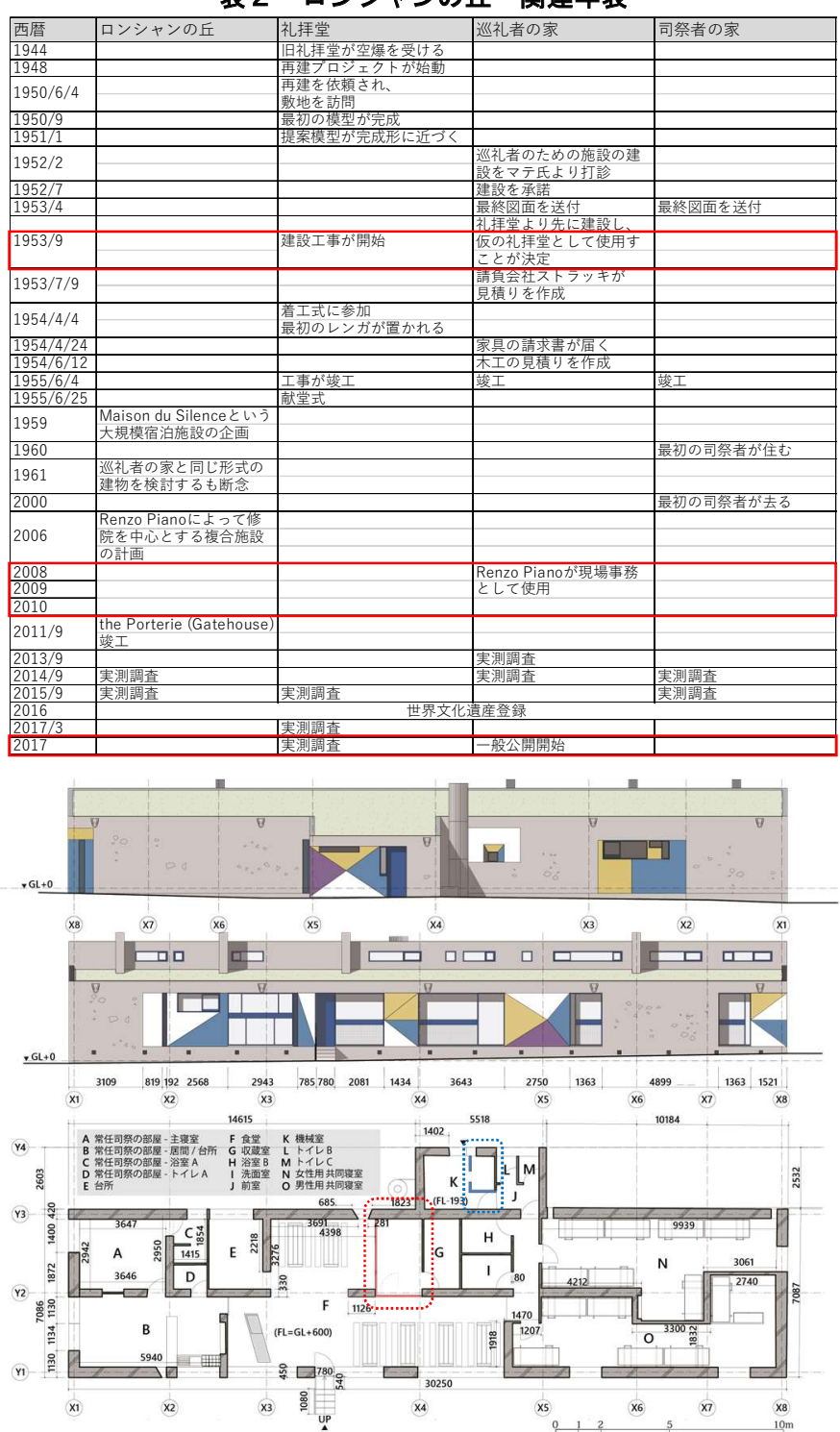

図 1 巡礼者の家 実測図面より 平面図・南北立面図

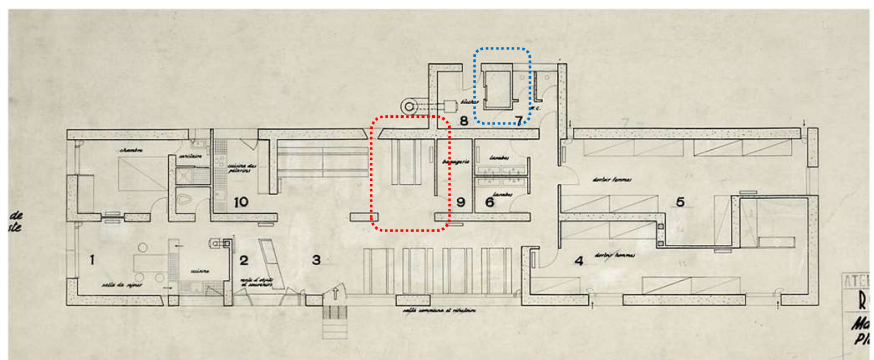

図 2 巡礼者の家 最終平面図 (FLC.7139，1954/02/26)

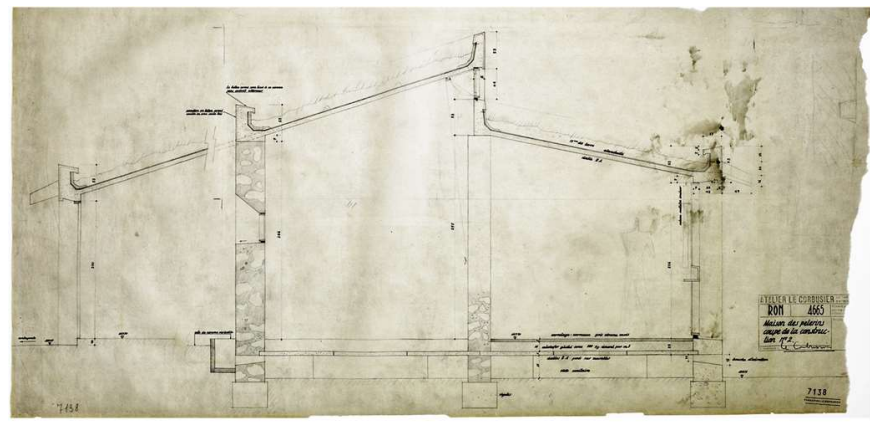

図 3 巡礼者の家 施工用断面図（FLC.07138） 


\section{4. 図面分析}

\section{1 ミュロンダン型（幾何学）の形態}

ル・コルビュジエは 1930 年代から 40 年にかけて構想したミュロ ンダン型 Murondin 住宅（壁（ミュール）と丸太木材（ロンダン）を 組み合わせた宿舎）を設計時に提案していた。東西に長く、丘の斜面 に沿って配置され、自然の風景の中に溶け込むことを意図された。ど のような敷地にも適合して建設されるこの住居形式は、礼扯堂から の景観を阻害することのない適切な選択であったことが窥える。周 囲の環境に呼応する音響的造形 forme acoustique の理念により唯一 の形態を創造された礼扯堂とは対照的であることが窥える。

断面構成では段違いの上段屋根の庇は巡礼者の家では初期案では ミュロンダン型と同じく飛び出すよう伸ばされていたが、施工段階 において出張りがなくなり平らな立ち上がりとなっている。また、屋 根の仕上げで植物（図面では Branches）が計画されているなど、両 者で同じ要素が引き継がれていることも示している(図 3,4) 注10)。

当時建設主任を任されたアンドレ・メゾニエ André Maisonnier (1923-2016） 注 9)の提案でコンクリート造に変更することになって いる。中に含められた瓦碚は大戦によって破壊された旧礼拝堂のも のであり、礼拝堂・司祭者の家にも同様に使用されている。礼拝堂と の調和を図りコストを抑えつつ耐久性を高めるためでもあった。

\section{2 モデュロール及び秩序の構成}

Vers une Architecture（1923）にて平面に関する多くの持論が展 開されている注11)。巡礼者の家においても秩序立ての理論が使用され ているかを、実測で得た数值を基に検証を行った。実測誤差・施工誤 差として $55 \mathrm{~mm}$ の範囲を設定、またル・コルビュジエの言説から 1000 分の 6 の誤差は許容範囲内とした。

垂直方向にて、 4 種の壁面（南・北・中央北・中央南面）では既存 図面ではモデュロール值の使用が見られるものの、実測值では約 20$30 \mathrm{~mm}$ の誤差があり許容範囲外とした。施工誤差と見られる。他、暖 炉の凹みでは実測值の平均值にて範囲内、北側空では範囲外であっ た。平面では、既存図面に寸法の記載はあるものの判読不可能なもの が主だったため、実測から得られた值にて検証した。72 項目検証し た結果、51 項目にてモデュロールの使用が確認された（表 3 ）。

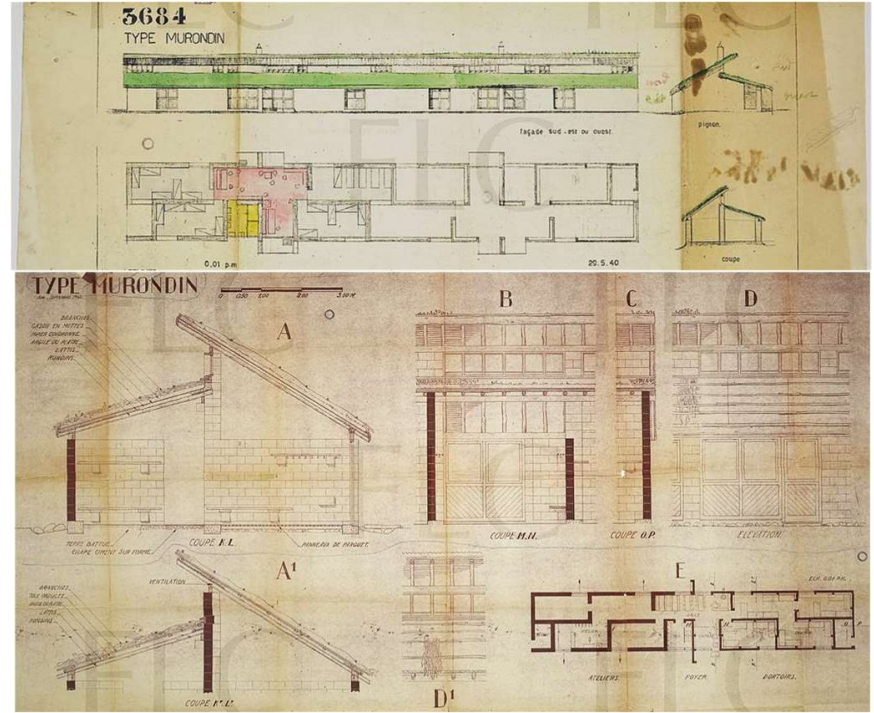

図 4 ミュロンダン型提案（上：FLC. 33592, 下 : FLC. 33597）

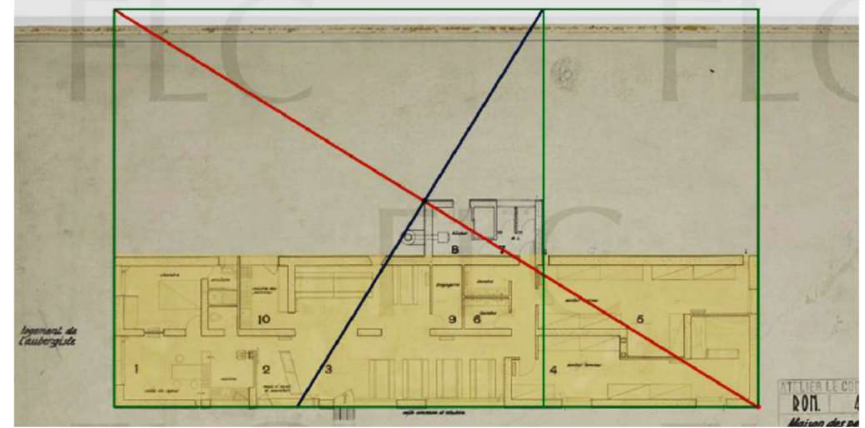

図 5 既存平面図による指標適合（FLC. 7139）

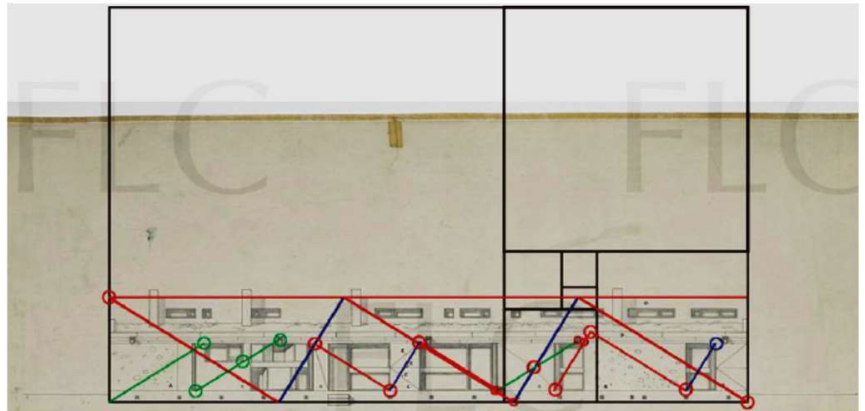

図 6 既存立面図による指標適合（FLC. 7141）

表 3 実測値のモデュロール検証（51/72 項目該当）

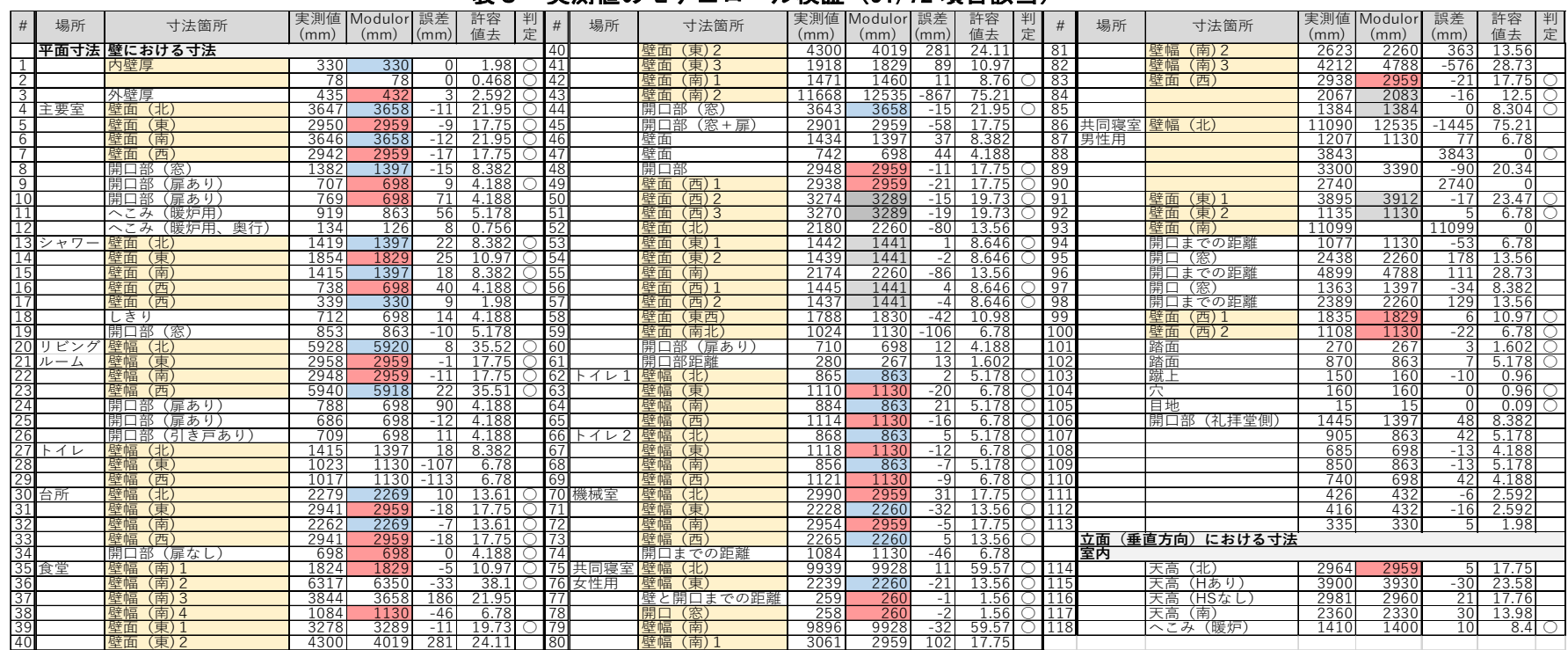


続いて黄金比の検証を行う。実測值より平面長辺方向の外壁寸法が $30250 \mathrm{~mm}$ となるが、これは内部におけるモデュロール值の寸法の和 であった。赤系列の数值の和にも同様の值がある。短辺方向の外壁寸 法 7087mm は、実測誤差を考慮すると $30250 \mathrm{~mm}$ に黄金比 $\Phi(1+\sqrt{ } 5)$ /2の三乗を掛け合わせたものであった。以上より、平面形態を黄金 長方形に当てはめ補助線を付加することで下記事項が導かれた。

・平面北側の凸部の先端が（1：2）の整数比及び（対角線）を用い て正確に導かれた（図 5 )。

・FL を基準とした立面寸法より、北・南面の垂直寸法は平面の長手 寸法 $30250 \mathrm{~mm}$ に 4 度の黄金比が乗算されており、立面の短辺と 平面の短辺は黄金比 (1: 1 ）の関係であった（図 6)。

作成した図面・既存図面（FLC 7141,7139）及び実測の数值より、 壁の厚みや開口部の幅など細部の様々な場面においてモデュロール が使用されていながらも、全体計画には 1920 年代の設計に代表され るトラセ・レギュラトールの適応が見出された。また、黄金比を基に する美の基準が形態の秩序として存在しており、平面と立面の関係 に数学的、幾何学的な調和が尊竿していることが分かった。なお Modulor II 内に食堂の内観写真が掲載されていることからも、両者 の間に関係性があることが確認できる（写真 2 )。

\section{3 ランドスケープ}

ル・コルビュジエは巡礼者の家の設計依頼を受ける上で 1940 年代 に実現しなかった教会のプロジェクトであるサン・ボーム計画 La Saint-Baume(la <Trouinade>)(1948)を意識していたことがマテ氏 のインタビューにおいて確認できた。この計画に関してル・コルビジ エは「全てが風景に敬意を表する事、すべてが風景に基づいて調整さ れており、全てが風景の表出そのものであった。と語っている。口 ンシャンの丘を訪れた際「ランドスケープの虜になった」と述べてお り、ロンシャンの丘の一連の計画においても風景を重視する計画で あることが伺える。既存図面（FLC 7317）より、設計段階において 礼拝堂と巡礼者の家の両者を天空の大きな円弧で捉えていたことが 確認できる。正円という幾何学によって、丘に調和をもたらす配置計 画が構想されていたことが窥える（図 7 ）。

丘全体の実測調查より巡礼者の家は設計図面（FLC 7480）の示寸 位置よりも礼扯堂に $10 \mathrm{~m}$ ほど接近していたことが分かった。フラン ス国土地理院の資料より、礼择堂の位置がずれたのではなく、巡礼者 の家が北東方向に移動（礼拝堂に接近）していたことが確認できた (図 8 )。礼拝堂からの視点で見ると北側壁面の視認面積が計画時よ り大きくなり、また人工緑化された屋上の傾斜が礼拝堂側へ顔を向 けているため芝生の認知効果が高まっている。礼拝堂と巡礼者の家 の間には人工的に盛土された丘があり、地面の芝生と屋上の芝生が 一体と化す効果が強調されていることが窥える（写真 3 )。

礼拝堂に面した北側は開口部の数が南側に比べて極端に少ない。信 者たちが多く過ごす食堂の窻より礼拝堂を眺め見ると、礼拝堂東側 に佇むマリア像が視野に収まることが確認出来た。この空のみ礼扯 堂南面と同様外部に広がっていく形状が取られており、既存図面 （FLC 7128）においても人の顔を近づけて外部を柕き見ることが想 定されていたことが確認できる。常任司祭者の部屋や台所、他の空か らは確認出来なかった。上述の位置関係の設計時との $10 \mathrm{~m}$ のズレに より、食堂の空から眺める礼扯堂はより大きく映され、額縁で切り取 られる範囲が現場との対話の中で強調されたと考えられる（図 9 )。

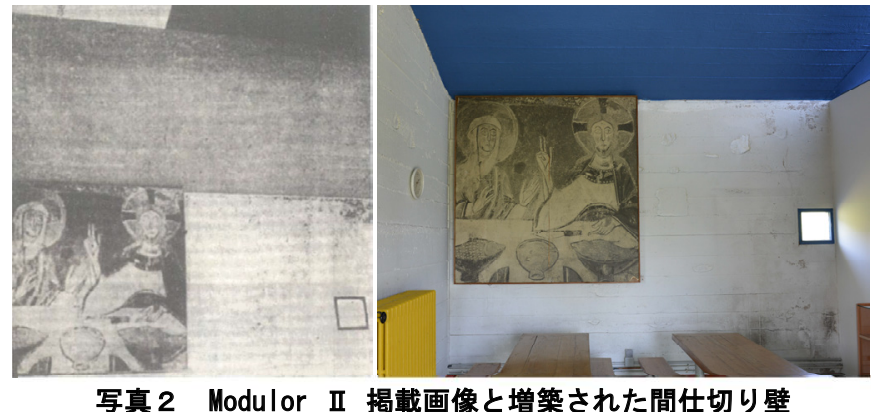

写真 2 Modulor II 掲載画像と増築された間仕切り壁

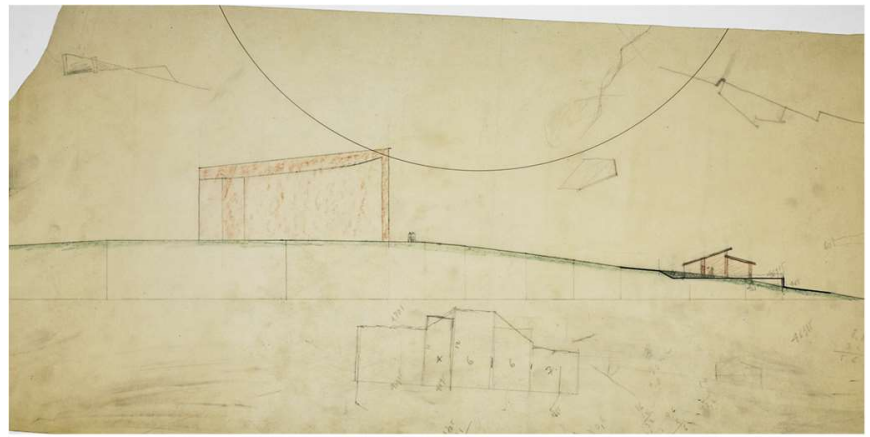

図 7 礼拝堂南突端部を通る正円（FLC. 7317）

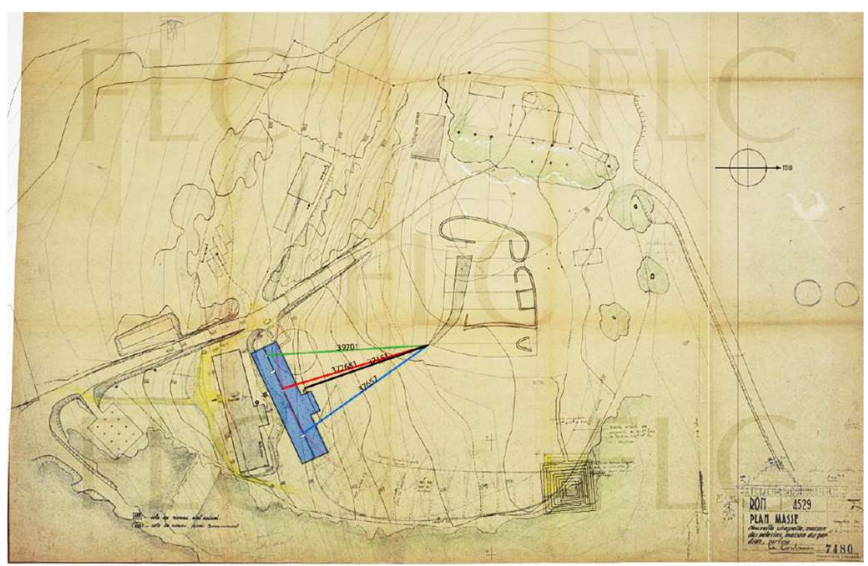

図 8 巡礼者の家の位置 : 実測プロット（FLC. 7480）
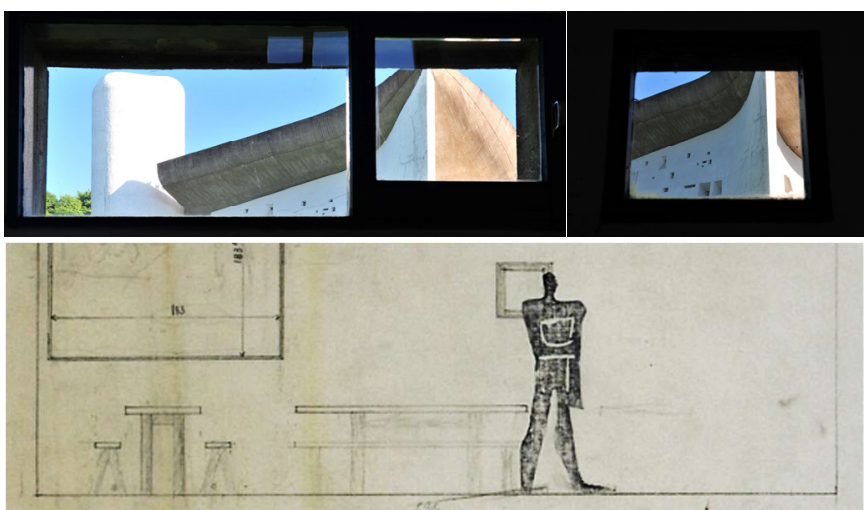

図 9 北面の礼拝堂を臨む空（FLC. 7128）

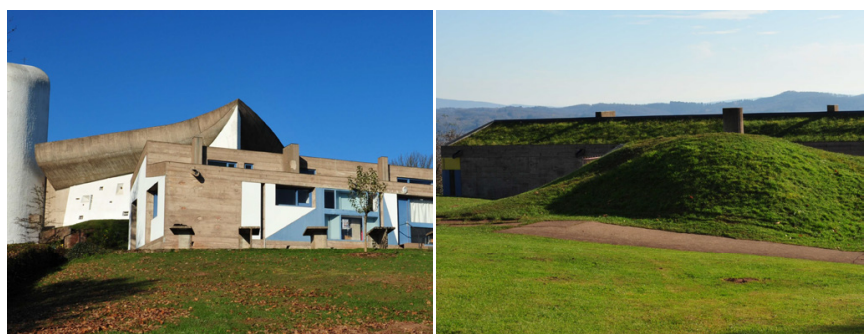

写真 3 南面見上げ(左) ・ 北面見下ろし(右) 


\section{4. 色彩評価}

巡礼者の家では建物の内部や外部に多様な色彩が用いられており、 強いゾーニングがなされている。各室の色彩空間は天井の色彩と光 と影、白い壁に反射した色彩によって構成されており、ハイサイドラ イトから光が入る角度や方向により多様に変化することが分かった。 外部の壁面で白く塗られた部分とコンクリートがそのまま表しにな っている構成は礼拝堂と共通している (写真 4 )。

ル・コルビュジエの色彩観を 1911 年の東方への旅の言説から時 代を辿り、色彩に対する空間への影響を整理した。その後、ル・コ ルビュジエが出版した色見本 Salubra I (1931), II （1959）を用いて 分析を行った。また、他作品との比較を行ったところ 1950 年代の 建築作品に見られる色彩感に基づいて配色が決定されていることが 分かった。外壁においては 1920 年代からのポリクロミー

Polychlomy の思想に基づきながらも建築的カモフラージュで使用 される色彩ではなく、一方で宗教的な思想のみに依存している訳で もなかった注 12$)$ 。内部空間においては、小規模でポリクロミーの思 想が確認できる他 4 つを選定したところ、サヴオア邸以前では壁面 に集中していた彩色が 50 年代以降では天井にも彩色箇所が拡張し ていった。更に使用される色味も Salubra I 、II の違いと同様に、 中間的な色味から原色よりの強い色味に変化していることが確認で きる(表 4,5 )。

天井面に彩色が施されたデュバル工場注 13)や、色彩面に反射した光 が他の面を彩る現象についてユニテ・ダビタシオンにおける記述注 14) を挙げていくと、極彩色と打ち放しコンクリートとの調和や、反射光 を利用することで空間に彩りをもたらすことが出来ることをル・コ ルビュジエは把握していたことが導かれる。また、床面には陶器を砕 いてモザイク柄になるよう配置するトレンカディス Trencadis とい う工法が用いられており、この工法はスペインにおいてカタルーニ ヤ・モデルニスモ期に見られたものであった注15)（図１０）。

上の内容をふまえル・コルビュジエの建築作品を通して見る中で、 巡礼者の家では(1)これまで使用されているボキャブラリーを使用し ながら彩色を施している、(2)色彩は Salubra I と Salubra II の変遷の 上に位置している、という 2 つの特徴が確認できた。

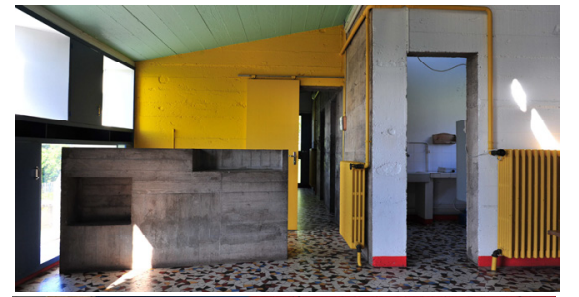

外観
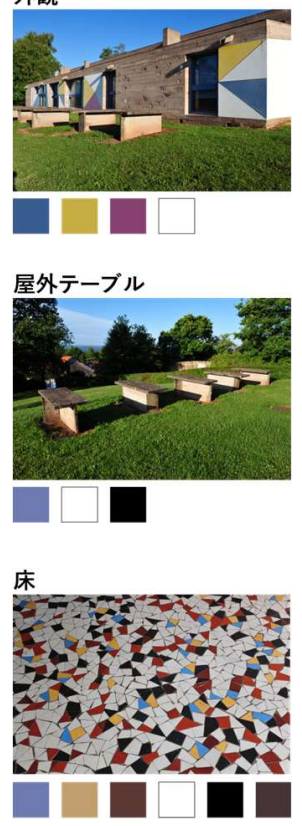

内部 壁・天井
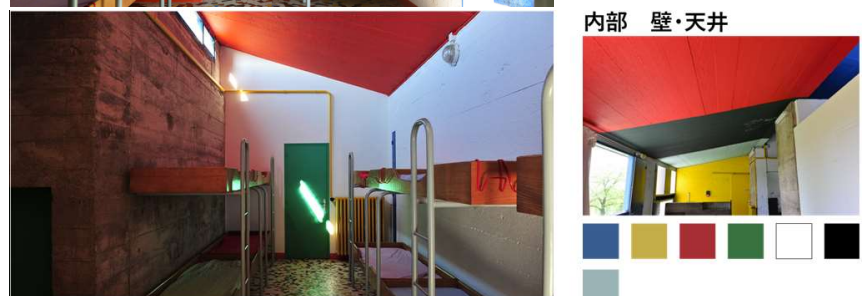

写真 4 （上から）食堂：西 - 東、共同寝室 : 男性用 - 女性用

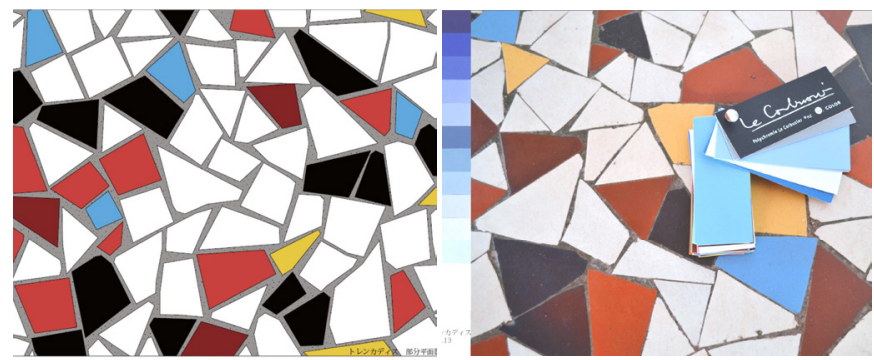

図 10 Trencadis Color Plan

表 4 彩色リスト

表 5 彩色構成図

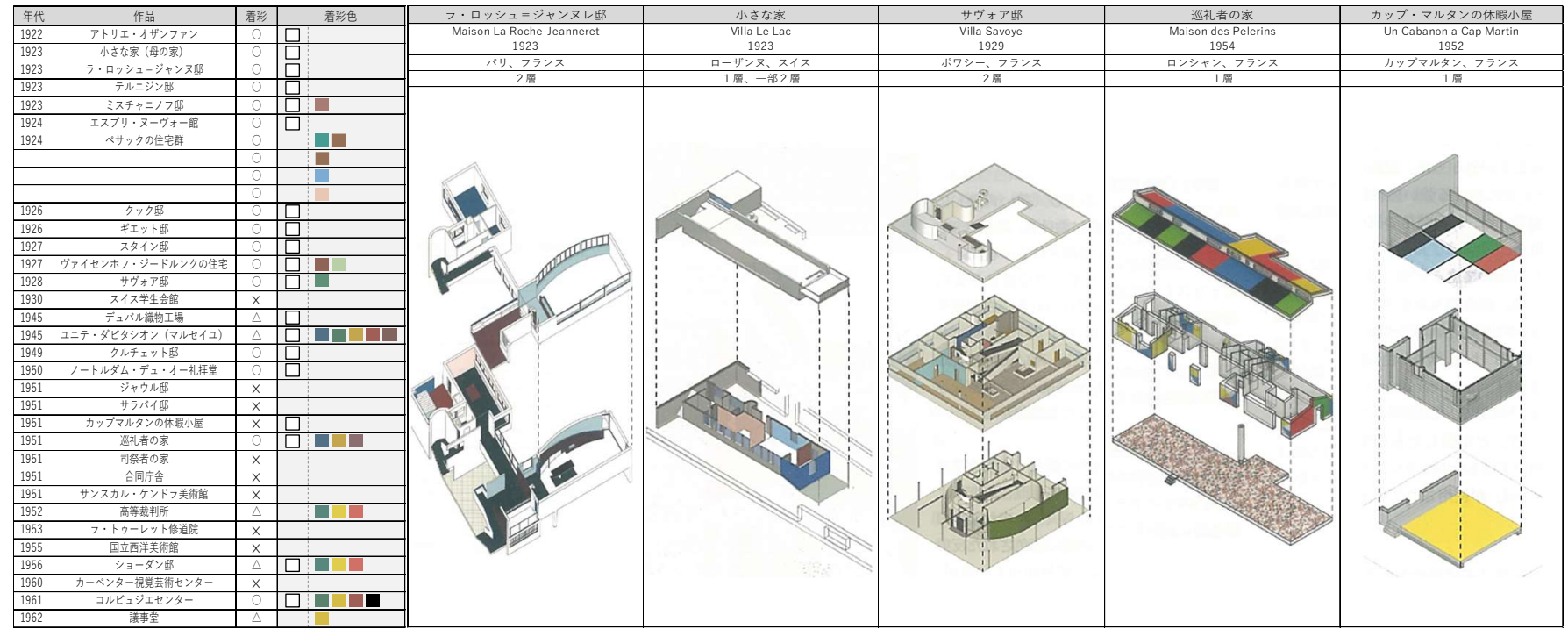




\section{5. おわりに}

本稿では、ル・コルビュジェが設計した巡礼者の家について 4 年 間の実測調查を通して明らかになった現在の施工状況を示した。ま た調査を経て得た成果物をもとに行った分析から下記 2 点を導いた。 ・巡礼者の家はロンシャンの丘全体における他要素との関係性のな かで、形態・配置・色彩の項目においてノートル・ダム・デュ・オ 一礼拝堂と結節された対比関係にあり、ル・コルビュジエが目指し た敷地全体の統合と調和の一端を担っていたこと

・両者の対比関係は、同時代の設計手法のみならず、東方への旅で得 た幾何学や色彩観、またそれらが時代を経て建築空間への操作とし て随所に表出されていることから、ロンシャンの丘に存在する礼帱 堂と巡礼者の家は、長年のル・コルビュジエの設計理念の延長に位 置すること

本研究において作成された図面等全ての情報は財団に提出され、

建築物の保存のために用いられる。竣工から時間が経過し、老朽化が 進む近代建築を調査し、保存することの重要性を示すことができた といえる。

今後は、司祭者の家を含む残りの建築群を捉え、ロンシャンの丘全 体としての構成理念を深く追求することができると考えている。

\section{謝辞}

本研究では今回の調査にご協力いただいたノートル・ダム・デュ・ オー慈善事業団体 L'A.O.N.D.H、同団体元副プレジデントのジャン・ フランソワ・マテ氏、ル・コルビジエ財団 Fondation Le Corbusier、 調査を実施した早稲田大学をはじめとする関係者の皆様に心から謝 意を示します。

\section{参考文献}

1)Le Corbusier: THE CHAPEL AT RONCHAMP, New York Frederick A Praeger, 1957

2)Le Corbusier: LE LIVRE DE RONCHAMP, Les Cahiers Forces vives Editec Impr. I.L.C. 1961

3)Le Corbusier: Modulor I , 1948 (邦訳 : 吉阪隆正 : モデュロール I , 鹿島出 版会, 1976)

4)Le Corbusier: Modulor II ，1954（邦訳 : 吉阪隆正 : モデュロール II，鹿島出 版会, 1976)

5)Le Corbusier: Voyage d'Orient, 1911

6)Le Corbusier: La Peinture moderne 1961

7)Le Corbusier: Les Constructions Murondins, 1956

8)Lahuerta, Juan Jose: Le Corbusier y España, Centre Cultura Contemporania Barcelona, 2005

9)Josep M Rovira, ed.,: Sert 1928-1979 Half a century of architecture complete work, Barcelona, Fundacion Joan Miro, 2005

10)Arthur Ruegg: Le Corbusier Polychromie Architecturale: Color Keyboards from 1931-1959, Birkhauser Architecture, 1932

11) Echelle-1, ed.,: Le Corbusier Plans, Fondation Le Corbusier, 2005-2011

\section{注}

注1）本実測調査は、2009 年から著書が行ってきたル・コルビュジエ研究の一 端である。L'A.O.N.D.H 副プレジデントのマテ氏を通し、記録のための 写真撮影、ビデオ撮影の申請「Declaration de Prise de Vues et Tournages」の許可を得て実施されたものである。2013 年より早稲田大 学にてル・コルビュジェの建築物の実測を行う研究プロジェクトを実施 しており、本稿においては、2013 年〜2014 年の期間、入江正之建築学 科名誉教授の研究室 (人見将敏、津田光甫、清水友稀，原周二郎、橋爪慧
太らと協働）にて行った内容を基としている。

なお、本論に使用した巡礼者の家、及び礼拝堂等の画像は、全て筆者が 撮影し、財団およびL'A.O.N.D.H より著書・論文等への使用許可を得た ものである。

注2) Le Corbusier: Le Corbusier œuvre complete 1952-1957 Vol.6, A.D.A. EDITA Tokyo, 1977, pp.16-41

注3）原著においては pp.278 にて Fig.136、邦訳版においては pp.193 にて第 136 図として掲載

注4) Echelle-1: op.cit., Vol.7

注5）早稲田大学にて、2016 年 6 月 29 日〜 8 月 7 日の期間「ル・コルビュジ エ ロンシャンの丘との対話 展」を開催した。 7 月 16 日に企画された シンポジウムIIにおいてマテ氏に貴重講演「ロンシャンの礼帱堂 建設 の経緯」をお話頂いている。パネリスト: 松郎洋、鈴木恂、白石哲雄（敬 称略・順不同）、モデレータ：古谷誠章

注6）巡礼者の家にレンゾ・ピアノの事務所機能が移設されるに伴い、電気等 設備機器も導入されている。

注7）・第一期：2013/05/14－05/14、一日間、04人 - 第二期 : 2014/06/11 - 06/12、二日間、05 人 - 第三期 : 2015/09/09 - 09/10、二日間、14 人 - 第四期 : 2017/03/27－03/29、三日間、09人

注8）巡礼者の家は一部コンクリート打ち放し仕上げであり、また壁の中に旧 礼拝堂の瓦碟を混ぜているため、表面に見られる僅かな凹凸や瓦碟の露 出により最大で数 $\mathrm{cm}$ の差が仕上げ面と瓦碟の間に確認された。

注9）メゾニエ氏は 2016 年 7 月 7 日に 93 歳で亡くなられた。マテ氏より何 度かお会いする機会のご提案を頂いていたが、実現に至ることは叶わな かった。この場を借りてご冥福をお祈りいたします。

注10) Echelle-1: op.cit., Vol.10

注11)Le Corbusier: Vers une Architecture nouvelle edition revue et augmentée, 2' Edition, Les Éditions G. Crès et Cie, Paris, Collection de “L’Esprit Nouveau”, Paris, 1925, pp.31-48（邦訳 : 吉阪隆正 : 建築をめ ざして, 鹿島出版会, 東京, 1967, pp.48-63)

注12)キリスト教においての祭礼における色について。白色は神の栄光/清らか さなどの意味を表しており、クリスマス後の降誕祭や復活において使用 する。赤色は愛や殉教を意味し、薔薇色は喜び、金色は王位や尊厳、威 風を意味し、青は希望、堅実さなどが挙げられる。

注13)Le Corbusier: Le Corbusier œuvre complete 1946-1952 Vol.5, A.D.A. EDITA Tokyo, 1978, pp.13

注14)Ibid., pp.195

注15)Trencadis の工法は Antonio Plácido Guillermo Gaudi y Cornet（18521926）（以下、ガウディと略記）の建築作品にも見られる手法である。 ル・コルビュジェは 1928 年にマドリッド、バルセロナを訪問しており、 当時 Josep Lluís Sert i López（1902-1983）の案内で町を散策し、ガウ ディの建築を見て回っていたことが分かった。両者のつながりにおいて はまだ検証が必要な事項が多く、本稿ではその可能性を述べるに留まる。 Josep M Rovira : op.cit., pp. 174-179, Lahuerta, Juan Jose: SERT AND GAUDÍ

Le Corbusier, Jose Luis Sert: Correspondances 1928-1965, Edition établie, présentée et annotée par Mathilde Tieleman, Paris, Editions du Linteau, 2009, pp.18-19, "Le Corbusier donna deux conférences devant des salles bondées et dans la journée, parcourut la ville en compagnie d'un groupe restreint dont faisait partie José Luis Sert en partageant avec eux ses impressions et admira Gaudi qu'il voyait pour la première fois. II se découvrit même certaines racines communes avec l'architecte l'architecte catalan car ses formes naturelles lui rappelaient certaines études faites avec son professeur l'Eplattenier en Suisse."

注16) Maison des Pèlerins の” e”の表記においては、”éと記載されているもの も存在する。Le Corbusier Plans や、André Maisonnier が木工家具等 に関して業者に送った手紙（Q1-7-174-001）では”é”゙使用されている。 一方、Fondation Le Corbusier や Colline Notre-Dame Du Haut の公式 HP では” èが使用されており、本稿では後者に習っている。

[2019 年 6 月 5 日原稿受理 2019 年 8 月 16 日採用決定］ 